\title{
Landmarks of Corporate Social Responsibilities in Romania
}

\author{
Mirela Teodorescu \\ University of Craiova, 13 A. I. Cuza Street, Craiova, 200585, Romania \\ E-mail address: daniamanolea@yahoo.com
}

\begin{abstract}
Currently, the image of a company, its corporate identity and culture have become of fundamental importance. Involvement in the community is necessary for a company that wants to ensure not only commercial success but also the respect in which society operates. Donations, sponsorship and corporate social responsibility are forms that companies can interact with the community in which it operates. The difference between a company's social responsibility and philanthropy is that the former involves the development of a strategy for community involvement and partnerships in which the company has in turn gain, while in the case of philanthropy, NGO strategy is oriented towards solving the problems of beneficiaries. Corporate Social Responsibility is a concept increasingly more present in Romanian business society. Obviously, the main driver in this process have established multinationals that have done a transfer of organizational culture locally. Like almost every important concept, undergo accelerated assimilation needs, has become more like a fashion initially, than as a result of full awareness of the needs. As expected in an economic and social framework rather immature and unstable social responsibility in Romania was valued more for its commercial valences than the ethical. In a market that was becoming increasingly competitive, players quickly discovered the potential of this dimension in the construction process of the image and reputation building, as the prerequisite for commercial success in the short and medium term (Hawkins, 2006). I want to emphasize from the outset that, the complexity of processes and phenomena referred to, the impact they have on the living standards and health of the population, Sectoral Strategies for Sustainable Development, which will be launched today, concern equally to state authorities at central and local level, and each of Romanian citizens. Therefore, it is natural to train as many social partners in public debates on sectoral strategies launched during the session, so that they integrate with society's expectations Romanian, medium and long term, says President Ion Iliescu in opening allocution of First Session on Strategy of Sustainable Development of Romania "Horizon 2025” (Ion Iliescu, 2004).
\end{abstract}

Keywords: corporate social responsibility; environment; sustainability; development; profitability; management

\section{INTRODUCTION}

The benefits of defining and implementing of a strategy for corporate social responsibility, for the company can vary depending on the area and the local or global community in which the company operates (Barney, 2001; Borowski, 2013). But it's worth mentioning that the benefits of such implementations are appearing in the medium term and long term (3-5 years). Exceptions are companies whose brand is already known on the market or the target community. Corporate Social Responsibility can be conducted under the 
coordination of human resources, the PR department or a Business-Developer or can be a freestanding structure to report to the general manager or in some cases directly to the Board. (Alexandra Dinita- General Manager - Free Communication).

\section{CORPORATE SOCIAL RESPONSIBILIOTY IN ROMANIA}

In fact, the normally lean toward the ethical balance - profitable in CR activity remains a subject discussed and disputed. The problem is global. KPMG International Survey of Corporate Responsibility Report 2005, survey conducted on a sample of nearly 1,600 representative companies globally, shows that the reasons why organizations implement CR activities are diverse, both economic (74\%) and ethical (53\%). The top ranks desire motivating employees to management concerns and reduce the risk or to stimulate innovation. As the authors conclude, "corporations are still looking for their way of construction of social engagement strategy, which in essence is different for each organization."

Late last year, KPMG has published a case study of CSR reporting in 41 countries, including Romania. Were analyzed information disclosed by the company in the period July 2012 - July 2013. If they were not available, were considered and information in 2011.

The study comprises two sections:

- Quantitative analysis of CSR information disclosed by the top 100 companies by revenue in each country (in total, 4,100 companies)

- Qualitative analysis of CSR reporting in the largest 250 companies in the world (according to Fortune Global 500 in 2012)

Even the results were not spectacular in Romania, it is important that CSR appeared and was implemented also in Romania by multinationals as a model then multiplied also in local companies these providing data to CSR. For the globally study, KPMG Romania inventoried top 100 companies by revenue in Romania. According to research by the middle of 2013, 69 of them had published CSR information, in one form or another:

- 28 published reports of local CSR (of which only 3 have used standard GRI - Global Reporting Initiative);

- 5 included sustainability information in their annual reports ordinary

- 36 of them CSR data transmitted to headquarters, to be included in the group reports

According to the study, from 2011 to now, the number of companies reporting CSR data increased (from 54 in 2011 to 69 in the present study).

Serbian Trader, Senior Partner of KPMG Romania, explains this trend: "Companies from Romanian market that are reluctant in terms of reporting on sustainable development will have to reconsider the position, as these reports are now mandatory in 10 of the largest economies in the world and is expected to become mandatory in all EU countries. Under current proposals at European level in the field of corporate responsibility reporting will become a legal obligation for large companies (whose number of employees exceeds 500, or whose balance exceeds 20 million or a net turnover higher 40 million). Also, a growing number scholarship listing conditions that includes reporting on environmental impact and corporate governance (Dima \& Vlăduţescu, 2012; Vlăduţescu, 2013). "As such, there is still not a recommended pattern of CR dimension within a company. In general plan, concern remains integrating CR in the development strategy and operational structure of an organization, in the context of an increasingly globalized economy. In Romania, the challenge is to overcome the 
current assumption, in the awareness that social responsibility is not only a tool to maximize value through building image, but an essential element of long-term success, which is directly related to social performance and environment of the community. A company's organic integration enhances society, sediment, strengthens (Hawkins, 2006). Designing connections with target audiences intangible sphere - where worth more, which are difficult to attack and difficult to be copied, which creates real value, where are indeed a difference.

Business involvement in the community has moved beyond the "well to done", going on the "have to be done" is not just for serious and sustained interest of consumers, but also for that opinion leaders recognize that their actions will be influenced by this trend (Gilda Lazar, 2013). But what is, in fact, corporate social responsibility? A definition of 'classic' would be: a long-term partnership with the community aimed at providing support in solving its social problems. President of Society General de Belgium, Viscount Etienne Davignon said that "social responsibility does not mean any charity or PR exercise, but a smart investment that benefits both the company and the entire community." Worldwide, CSR has become a part of everyday business. Internationally renowned companies investing in such programs an important part of their turnover. The budgets of the organizations to develop partnerships with community often reach rates that, at first glance, seem downright giddy. These amounts, however, represent in view of the managers of these organizations, a long-term investment, with significant results for the business. In Romania, CSR is a relatively new concept imported by international companies operating locally. Followed strategies are developed by multinational companies globally, sometimes tailored to local conditions. They reveal but lack of creativity: a few standard types of corporate programs are developed in Romania.

The types of 'standard' programs include donations, social welfare programs, sponsorships, support humanitarian foundations, corporate events, funding scientific or research projects, educational programs, support to disadvantaged people, environmental protection programs. Sophocles said that "any benefactor thinks a little at himself". In the case of Romanian companies, this concept underlies the development of relationships with the community, the main goal - if not unique - the development of corporate social programs being the publicity in the media. Commitment to the community of these organizations is often short term and has no real basis. However, CSR has become in Romania, a concept adopted by more companies. There is interest, there are even national recognition, revealed by the existence of awards to companies that have demonstrated active involvement in local community life and ongoing commitment to satisfying its needs. To our pride, among these include JTI Romania, which has proved consistently supported programs eight years as a good citizen of the community (Gilda Lazar, 2013).

In 2008, the third edition of CORE Conference: CSR and Integration, the teachers of the Academy of Economic Studies, Stancu Alin and Olteanu Valeria have approached the subject: Corporate Social Responsibility in Romania From the EU Perspective. In the article, the authors presented the evolution of corporate social responsibility in Romania, a post communist country, by highlighting the main achievements of the government and the actors involved in this process of change. They start from the premise that a company has a role in society, is responsible not only for payment of taxes and compensation of employees, but also adherence to quality standards for products and services and environmental protection. The large companies have taken action, and changed the business model and take into account social responsibility in relation to stakeholders and influence on the environment.

The European Commission has expressed its position regarding the CSR in The Green Paper document. In these conditions, Laurence Eberhard-Harribey (2012) sustain that CSR and business ethics have much in common: 
- CSR follows the company's decision, it is a voluntary element;

- CSR economically justified, being seen as an investment and not a cost;

- CSR means more than comply with the law.

The authors argue in the article that after 1989, the post-communist Romania has taken the first steps toward capitalism replacing the planned economy with market economy. The new economic environment was full of turbulence, due to integration in the European Union, the globalization and liberalization of domestic markets. So our country has been in a continuous transformation, the development had to achieve certain economic indicators.

In terms of government action, great efforts were made in the first place, to align national legislation to the European one. In terms of ecology and environmental protection, the Government has made great progress. Also to stimulate companies to get involved in community issues, sponsorship law was instituted whereby they can donate more than $3 \%$ of their turnover, but not more than $20 \%$ of the profit tax. Sponsorships can afford to make only large companies with major business figures, not SMEs (Siminică \& Traistaru, 2013; Traistaru \& Avram, 2014).

Another important action of the Government is represented by $2 \%$ provision whereby income tax payers can donate $2 \%$ of it by NGOs, churches, associations. An important step was made in 2007, when it was established the CSR Division, under the direction of the Secretary of State. Division has the power of CSR policy deployment, in cooperation with the state, the NGOs, civil society to promote the concept of CSR locally among Romanian companies.

In business, CSR begins to take shape. Multinational companies are mostly involved in CSR activities because management transfer good practices from the parent company to local branches in the country. A good example is the company Petrom, which included CSR in business strategy and launched a major campaign to promote the slogan "respect for the future."

In the article, the authors mention a research conducted on a sample of 205 firms, concerning the level of inclusion of CSR in their business model. Thus, $94 \%$ of respondents agreed with the idea that in addition to interest in profitability, the company should be involved in the development of the community where it operates. Research has revealed that the Romanian companies usually engage in social projects in the short term, and CSR is not included in long-term business strategy (Stavre, 2012; Enachescu, 2013; Teodorescu, 2014).

In addition, the main reason why companies become more responsible is pressure increasing from stakeholders. Thus, customers are better informed, Non-Governmental Organizations and the media is pressuring companies to reduce interference on the environment. All these elements stimulate socially responsible behavior and actions of CSR create a positive image of the company in question (Vladutescu, 2013).

The research also reveals the fact that the person responsible for CSR activities, in most of cases, is the general manager of the company. PR and marketing departments are also in charge of CSR projects.

The study highlights the fact that most Romanian companies disagree with the idea that customers buy the company's products due to their involvement in CSR projects, but believes that in the future consumers will appreciate socially responsible investment of companies.

Another finding of the study shows that Romanian companies are focused more on the internal dimension of CSR, concentrate more their attention to their employees. Other companies but creates partnerships with universities in order to select such prospective employees. Social issues, environmental issues as well collaboration with NGOs become priority of CSR agendas of these companies. 
In the performed analysis, the authors studied consumers and the public perception of CSR. The authors believe that those who buy products / services can greatly influence the development of a company. Such the research has been undertaken on a sample of 915 consumers. Customers consider working in community service, primarily are entities represented by the media, followed by religious groups and NGOs. Another important element that resulted from the research is: Romanian consumers do not perceive the companies as socially responsible (on a scale of 1-5, Romanian companies were rated 2.5). In terms of buying behavior, consumers have shown indifference to the RSC factor in buying a product / service (on a scale of 1-5, the score was 3.07) (Smarandache, 2002, 2005, 2010; Grabara, Kolcun \& Kot, 2014).

Corporate Social Responsibility begins to replicate the dynamics of the global trend, as Romanian companies and executives become more aware of its relevance in differentiating companies, according to the study CSR Trends and Realities in Romania, conducted by CSRMedia.ro and Ernst \& Young Romania. Thus, $78 \%$ of respondents said that the company they represent has a dedicated CSR strategy, while $67 \%$ of them consider that the general interest for CSR grew in the last 12 months. Supporting the same idea, more than three quarters of the surveyed companies said they have an annual dedicated budget for CSR actions. Half of these companies say that the budget in 2013 is similar to 2012, while only $16 \%$ of companies recorded an increase between 5-10\%. Regarding the allocated amount of money, $66 \%$ of respondents said that the average CSR project does not exceed EUR 10.000.

"The study comes as a support to all stakeholders and decision makers in companies, given that corporate social responsibility is gradually becoming an important component of business strategy. This is no longer the task of strictly one person (or department) but extends to leaders at all levels, along with the increasing importance of dialogue with both internal and external company stakeholders. We're basically talking about adopting a business model that is socially responsible to it employees as well as to its partners and customers, to authorities and communities. We are witnessing a period in which a company is not only evaluated through its profits but also by the ways in which a portion of this returns to society, other than in the form of taxes." - asserts George Carpov consultant CSRMedia.ro

The study conducted by CSRMedia.ro and Ernst \& Young Romania is based on a survey conducted between 10 April and 10 May, 2013. This is the first study in Romania dedicated to CSR as a strategic positioning tool and its respondents were mostly representatives of companies that have CSR activities. The report analyzes the responses of 77 top managers and experts in the area regarding the initiated and implemented corporate responsibility projects in 2012 and the prospects for CSR in the near future. 54\% of these companies have revenues of over EUR 10 mil. "Even if CSR involvement was a practice initiated by subsidiaries of multinational companies, as part of their values, this is no longer an abstract concept for Romanian companies. The next step now is that it becomes a strategic area for as many Romanian private companies and public institutions as possible. The fact that $41 \%$ of respondents are leaders or members of the company board of directors and $82 \%$ of companies have their leaders actively involved in CSR efforts, clearly shows the importance they assign to corporate social responsibility." - asserts Bogdan Ion, Country Managing Partner Ernst \& Young Romania (Dima \& Man, 2012; Dima, 2013). 
Alina Liciu, Director of consulting agency The Azores shows the importance of the EU attaches to food waste and what are the financial benefits or image that would get the companies would be involved in solving this problem. There are companies who take models from other countries where the projects were successful. Much has already changed for the better in how people relate to those around them and the community. We passed the time of the individual solutions. We are becoming more open understanding that we need to build solutions together because if we live, work and spend time with others, many of the problems we face and the solutions that will help us are in this community (Colhon, 2012; Colhon, 2013; Buşu \& Buşu, 2014).

Those who have already had an experience point of engagement, which brought satisfaction, understand these things, they are looking to continue to promote these ideas in the community constantly and organized, along with other leaders who share their vision. They know it's important to start somewhere and see the mechanism community foundation a great way to multiply the number of people who give something to community and do something for the community. "90 million tons of food are wasted annually in the European Union. This amount represents $40 \%$ of all food. Waste produced throughout the supply chain, from production, sale to the final consumer. Wasting food is a phenomenon that affects society, environment and economy. The European Commission has identified the food industry as a key sector where resource efficiency can be improved. In industrialized countries, most of the waste occurs in retail and the final consumer."

Food waste in the UK is recognized as an economic, social and ecological issue. Since the launch of the national campaign "Love Food Hate Waste", in 2007, sought various solutions to reduce this waste, both the central government and the municipalities or retailers. According to the study "Vision 2020", $40 \%$ of British food reaches landfill, representing around 15 million tons of waste each year.

The study calls on all parties to join forces to stop any food to reach the landfill. One of the measures recommended is to gather all the food waste from homes and businesses in the UK. They can be reused as a valuable resource for power, heat and nutrients in agriculture. Romania aims to follow the British model. In June 2013 the Ministry of Environment and Climate Change of Romania launched the "Think. Eat. Save ". It will take the British model of collaboration between authorities, business and communities. According to official statements, the amount of food waste in Romania amounted to five million tons per year. The objective of the Ministry is to reduce this amount by $50 \%$ by 2020 . I'd like to see in Romania increased awareness campaigns, asserts Alina Liciu, information and education both from the authorities, producers and retailers. Wasting food is a phenomenon that affects society, environment and economy. Closer monitoring of the amount of food wasted and an analysis of why throw is handy and has a guaranteed efficiency. In addition, the resulting compost from organic waste we can re-use for electricity production or nutrients, resulting in resource efficiency. To reduce the amount of food waste is one of the simplest ways to reduce the environmental impact and the effects of global warming (Petres, 1994; Borowski, 2014).

Among the most active companies includes Holcim Romania. Daniel Bach - CEO, Holcim Romania said in an interview: "Sustainable development is achieved through both systems and the company's shares, and the attitude of each of the employees and managers. We work in an industry that relies significantly on natural resources and are fully aware of the responsibility we have to protect them. Therefore, we have undertaken to increase efficiency and profitability, while protecting the environment, respecting the communities located near our manufacturing facilities and contributing to their development". Orange Romania sees the concept of social responsibility, compliance with standards of business ethics, near the 
community, contributing to its development through technology and expertise at its disposal, maintaining an open dialogue with all partners interact with customers, employees, suppliers, community and to the shareholders and the state institutions. Orange has chosen to support communication mainly based initiatives that aim to contribute to increasing the active involvement of people in the community.

Orange has been involved in professional development of students by offering training programs for them, support an educational project dedicated to children with visual impairment and hearing in order to integrate them into society, helping to increase people's access to communication services is the first mobile operator of Universal Service provider by implementing isolated tele-centres in Romania. "We believe that Orange may have a significant positive impact in community development and therefore the company has taken this responsibility very seriously. We have over 2,000 employees, we have invested so far in Romania over 1 billion $\$$ and we have developed relationships with many partners, relationships based on trust and honesty. To this is added the various initiatives supported by Orange in the field of education, communication, social. All this means corporate social responsibility that benefits not only the community in which we operate, but also Orange" said Richard Moat, Chief Executive Officer of Orange Romania.

\section{CONCLUSIONS}

Corporate Social Responsibility in Romania is still in the growth stage. Only multinational companies are those who are concerned about this area because of their organizational culture. However, some companies publish CSR reports or include in their annual report on socially responsible activities they undertook. Romanian companies use CSR as a tactical tool and, therefore, most CSR projects in Romania are short term. The authors also argue the fact that the media and NGOs are not all too active in promoting this concept. At governmental level, CSR strategy is, in the largely imported from the EU. The period 20132025 is due to the trend of sustainable growth trajectory of Romania, close to those of countries with high level of development, the main effects of EU integration, as well as of our own efforts and will be estimated by the reduction in the absolute gap and relative to the average level of the European Union. For the time horizon, the setting of targets in terms of quality, especially quantitative, it will be possible in a relatively small number of indicators. What seems important for the future is not so prospective numerical scale of our development, and especially the sense of quality and speed of evolution will cross the path of scientific and technological progress worldwide (Ion Iliescu, 2004).

\section{References}

[1] J. B. Barney, Academy of Management Review 26(1) (2001) 41-56.

[2] A. Borowski, International Letters of Social and Humanistic Sciences 4 (2013) 70-74.

[3] Brown R. Lester (2006). PLAN B 2.0 - Rescuing a Planet Under Stress and a Civilization in Trouble. Earth Policy Institute.

[4] Ioan Constantin Dima, Ştefan Vlăduţescu (2012). Persuasion elements used in Logistical negotiation: Persuasive logistical negotiation. Saarbrucken: LAP Lambert Academic Publishing. 
[5] Alexandra Dinita. Interview 2013 - General Manager of Free Communication Company. Internet Source.

[6] Laurence Eberhard-Harribey (2012). De la RSE au developpement territorial durable: le role clef de l'ingenierie territoriale dans le departement des Landes, Etude de cas. Internet Source.

[7] A. Borowski, International Letters of Social and Humanistic Sciences 14 (2014) 7-17.

[8] David E. Hawkins (2006). Corporate Social Responsibility - Balancing Tomorrow's Sustainability and Today's Profitability. Palgrave MacMillan.

[9] Ştefan Vlăduţescu (2014). Eight Computational-Communicative Operations of Building Information. Mitteilungen Klosterneuburg.

[10] Ion Iliescu, Allocution - Debate Session Sustainable Development Strategy of Romania "Horizon 2025” Parliament Palace, Romania, 27 January 2004. Internet Source.

[11] KPMG 2005 International Survey of Corporate Responsibility Report. Internet Source.

[12] Alina Liciu Managing Partner - The Azores Consulting Company (2013). Interview by Irina Breniuc. Internet Source.

[13] KPMG 2013International Survey of Corporate Responsibility Report. Internet Source.

[14] Gilda Lazar, Corporate Affairs Director - JT International Romania. Internet Source.

[15] Ştefan Vlăduţescu, International Letters of Social and Humanistic Sciences 10(2) (2014) 100-106.

[16] Alin Stancu, Valeria Olteanu (2008). CORE Conference: CSR and Integration. Bucharest Academy of Economic Studies.

[17] Mirela Teodorescu, Dan Ionescu, International Letters of Social and Humanistic Sciences 14 (2014) 50-58.

[18] F. Smarandache, Ş. Vlăduţescu (2014). Neutrosophic Emergences and Incidences in Communication and Information. Saarbrucken: LAP Lambert Academic Publishing.

[19] Aurelia Traistaru, Marioara Avram, International Letters of Social and Humanistic Sciences 13 (2014) 79-88.

[20] W. Beckerman, Environmental Values 3 (1994) 191-209.

[21] O. V. Buşu, O. C. Buşu, International Letters of Social and Humanistic Sciences 9 (2014) 100-107.

[22] Mihaela Colhon, Computer Science and Information Systems/ComSIS 9(3) (2012) 1231-1247.

[23] A. Borowski, International Letters of Social and Humanistic Sciences 6 (2013) 86-90.

[24] Ştefan Vlăduţescu (2013). Principle of the Irrepressible Emergence of the Message. Jokull.

[25] Mihaela Colhon (2013). Automatic Lexical Alignment between Syntactically Weak Related Languages. Application for English and Romanian. In Computational Collective Intelligence. Technologies and Applications (pp. 266-275). Springer Berlin Heidelberg. 
[26] E. A. Cotoc, A. Traistaru, A. Stoica (2013). Systems of Environmental Management. European.

[27] Ioan Constantin Dima, Ştefan Vlăduţescu (2012). Persuasion elements used in logistical negotiation: Persuasive logistical negotiation. Saarbrucken: LAP Lambert Academic Publishing.

[28] V. A. Enachescu, Journal of Community Positive Practices 13(2) (2013).

[29] S. Kot, B. Ślusarczyk, M. Starostka-Patyk (2013). Information Systems Supporting Cooperation in Supply Chains. In: Supply Chain Management. Fundamental and Support Elements. Monograph. Edited by Virgil Popa, Marta Starostka-Patyk, Czestochowa.

[30] Ştefan Vlăduţescu (2013). Principle of the Irrepressible Emergence of the Message. Jokull.

[31] A. Borowski, International Letters of Social and Humanistic Sciences 11 (2014) 1-168.

[32] I. C. Dima (2013). Industrial Production Management in Flexible Manufacturing Systems. IGI Global SUA.

[33] Ion Stavre (2012). Internet and digital technology - influences on audiovisual communication and on teaching at master's degree level, Valencia, 2012, Published by International Association of Technology, Education and Development - ISBN: 978-84-615-5563-5

[34] Ştefan Vlăduţescu (2013). Three Diachronic Paradigms of Communication. International.

[35] A. Borowski, International Letters of Social and Humanistic Sciences 14 (2014) 33-41.

[36] A. McWilliams, D. Siegel, Strategic Management Journal 21 (2000) 603-609.

[37] Ştefan Vlăduţescu (2013). What kind of communication is philosophy. Jokull.

[38] A. McWilliams, D. S. Siegel, P. M. Wright, Journal of Management Studies 43(1) (2006) 1-18.

[39] Tom Peters (1994). Liberation Management. Fawcett.

[40] Ş. Vlăduţescu, E. M. Ciupercă (2013). Next Flood Level of Communication: Social Networks. Aachen: Shaker Verlag.

[41] F. Smarandache (2010). Strategy on T, I, F Operators. A Kernel Infrastructure in Neutrosophic Logic. In F. Smarandache (Ed.), Multispace and Multistructure, Neutrosophic Transdisciplinariry (100 Collected Papers of Sciences) (pp. 414-419). Vol. 4. Hanko: NESP.

[42] Janusz Grabara, Michal Kolcun, Sebastian Kot, International Journal of Education and Research 2(2) (2014).

[43] D. S. Siegel, Academy of Management Perspectives 23(3) (2009) 5-16.

[44] Aurelia Traistaru (2013). Consolidation of the green marketing profile in current austerity period. Jokull.

[45] Ştefan Vlăduţescu (2013). Communication Beings: Four Communication Prototypical Figures. International. 
[46] Ioan Constantin Dima (2013). Organisational strategies - a systemic approach - on the example of the automotive industry. Saarbrucken: LAP Lambert Academic Publishing.

[47] F. Smarandache, Multiple Valued Logic 8(3) (2002) 297-384.

[48] Ioan Constantin Dima (2013). Industrial Production Management in Flexible Manufacturing Systems. IGI Global USA.

[49] F. Smarandache (2005). A Unifying Field in Logics: Neutrsophic Logic. Neutrosophy Neutrosophic Set, Neutrosophic Probability. Infinite Study.

[50] Bianca Teodorescu, International Letters of Social and Humanistic Sciences 12 (2014) 73-78.

[51] Ştefan Vlăduţescu, American International Journal of Contemporary Research 3(10) (2013).

[52] Vladimir Modrak, Petre Bosun, International Letters of Social and Humanistic Sciences 14 (2014) 66-72.

[53] Marian Siminică, Aurelia Traistaru, International Journal of Education and Research 1(12) (2013).

[54] Janusz Grabara, Petre Bosun, International Letters of Social and Humanistic Sciences 14 (2014) 59-65.

[55] Florentin Smarandache, Ştefan Vlăduţescu, (2014). Neutrosophic Emergences and Incidences in Communication and Information. Saarbrucken: LAP Lambert Academic Publishing. 